\title{
GREITOSIOS MEDICINOS PAGALBOS STOTIES SPECIALISTŲ KOMANDINIO DARBO EFEKTYVUMAS
}

\author{
Genovaitė Eismontiene் ${ }^{1}$, Lina Gedrimé $\dot{2}^{2,3}$, Ramunẻ Žilinskiené $\dot{ }^{2}$, Almeda Kuriené2, \\ Erika Davydenko ${ }^{2,4}$, Natalja Fatkulina ${ }^{2}$ \\ ${ }^{1}$ Klaipédos universitetas, ${ }^{2}$ Vilniaus universiteto Medicinos fakulteto Sveikatos mokslu institutas, \\ ${ }^{3}$ Respublikiné Klaipédos ligonine, ${ }^{4}$ Respublikiné Vilniaus universitetinè ligoniné
}

Raktažodžiai: komandinis darbas, GMP slaugytoja, komanda, skubios pagalbos komanda, komandos efektyvumas, greitoji medicinos pagalba.

\section{Santrauka}

Skubiosios pagalbos komandinio darbo kokybè lemia paciento sveikatos būklę ir išgyvenamumą. Greitosios medicinos pagalbos (toliau - GMP) struktūra vienoda visuose Lietuvos miestuose: dispečerinè tarnyba, atliekanti koordinatoriaus vaidmenį, ir išvažiuojamosios brigados. Brigadoje dirba ne mažiau kaip du žmonès. Vienas yra komandos lyderis, priimantis sprendimus ir palaikantis ryši su dispečerine tarnyba. Šio darbo tikslas - įvertinti GMP stoties specialistų komandinio darbo efektyvumą komandos narių požiūriu.

Vieno iš didžiujų Lietuvos miestų GMP stotyje 2019 metais balandžio mènesị buvo atliktas kiekybinis tyrimas, kuriame dalyvavo 60 GMP stoties specialistų: gydytojai, slaugytojai, slaugytojai-dispečeriai, paramedikai, vairuotojai.

Rezultatai ir išvados. Esant didelei skirtingų komandų įvairovei, svarbu suvokti, kokiai komandai priklausoma, žinoti tos komandos uždavinius, tikslus ir perspektyvas. Komandinio darbo svarba asmens sveikatos priežiūroje sietina su ịvairių specializacijų darbuotojų bendradarbiavimo poreikiais. Komandinis darbas padeda taupyti ir racionaliau naudoti finansinius ir žmogiškuosius sveikatos priežiūros išteklius, užtikrinti geresnę paslaugų kokybę, sumažinti gydymo klaidų tikimybę. Atlikto tyrimo rezultatai gali būti naudingi ir paslaugų teikèjams (GMP komandoms), ir jų gavejjams (pacientams).

\section{Ivadas}

Greitosios medicinos pagalbos stočių tinklas yra sudètingas įvairiai dirbančių komandų, turinčių bendrus tikslus, santykių kompleksas. Dabartinès GMP organizacijos Lietuvoje nepakankamai dèmesio skiria komandiniam darbui ir jo efektyvinimui.

Komandinio darbo svarba ir jo efektyvinimo problemos šiandieninejje visuomenejje sietinos su ịvairių specializacijų darbuotojų bendradarbiavimo poreikiais. Komandiniam darbui keliami nauji valdymo iššūkiai, reikalaujama formuoti kompetentingas, efektyviai veikiančias komandas. Kad būtų užtikrintas efektyvus ir kokybiškas darbas, nuolat tobulinami komandinio darbo igūdžiai, personalas skatinamas domètis naujovèmis. Komandoje dirbantys žmonès privalo ne tik turèti žinių apie atliekamą darbą, jo svarbą, bet ir gebèti tas žinias efektyviai panaudoti [3]. Efektyvi komanda - kiekvieno nario atsakingas ịsitraukimas ị veiklą, siekiant užsibrěžtų asmens ir komandos tikslų.

Komandinio darbo efektyvumas ypač juntamas medicinos įstaigose. Sveikatos priežiūros ir gydymo procese dalyvauja ịvairių sričiu gydytojai, bendruomenès slaugytojos, diagnostikos specialistai, gydymo įstaigu administratoriai, socialiniai darbuotojai, psichologai, techninis personalas ir kiti. L. Marmienè ir kt. (2015) teigia, kad „Būtent komandiniu darbu pagrịsta visa sveikatos priežiūros sistema. Jis sietinas su ịvairiais pokyčiais, naujovėmis, ịvairių specializacijų darbuotojų bendradarbiavimu“" [5]. Komandinio darbo tikslas - orientuotis ị darbinę užduotị komandos nariams, dirbantiems kaip vientisas organizmas. Komandos nariai privalo prisiimti atsakomybę ne tik už savo, bet ir už visos komandos veiklos rezultatus. Pasak N. Žemaitienès (2011), komandoje dirbantys sveikatos priežiūros specialistai yra labiau patenkinti savo darbu, vienam asmeniui tenka mažesnis krūvis, sumažeja darbe patiriamo streso ir perdegimo tikimybè. Komandinio darbo pagrindas - bendradarbiavimas ir pasitikejjimas. Tyrimai rodo, kad komandai, kurioje bendradarbiauja kelių sričiu specialistai, sutariančiai dèl darbo modelio, galima tikètis pagalbos, adekvatumo, paciento pasitenkinimo, komandos veiklos nuoseklumo, t. y. slaugos, pagalbos, priežiūros užtikrinimo [7]. 
Tikslas - išanalizuoti GMP stotyje dirbančių specialistų komandinio darbo efektyvumą.

\section{Tyrimo metodai ir medžiaga}

Temos nagrinejjimui pasirinktas kiekybinių tyrimų metodas - anonimine anketinè apklausa (toliau - apklausa) ir mokslinès literatūros turinio analizè [19]. Mokslinių straipsnių pasirinkta tema ieškota Klaipėdos universiteto virtualios bibliotekos PubMed, MEDLINE, EBSCO Publishing, SocINDEX with Full Text, Google Scholar duomenų bazèse, Lietuvos aukštujų mokyklų bei mokslo institucijų leidiniuose „Visuomenès sveikata“, „Sveikatos mokslai“. Analizei atrinkta 20 mokslinių studijų, susijusių su nagrinėjama tema.

Anoniminei apklausai buvo parengtas klausimynas, kuri sudarè 20 klausimų. Pirmieji 5 klausimai skirti išsiaiškinti GMP specialistų sociodemografinius duomenis, dirbančiųjų pasirengimą ir poziciją, dirbant komandinį darbą. 6-14 klausimai skirti išsiaiškinti komandinio darbo aspektus, t.y. komandinio darbo vertinimą, vertybes, veiklos rezultatus. 15-20 klausimai - atskleisti respondentų nuomonę apie efektyvų komandinị darbą, komandinio darbo gerinimo siekius.

Tyrimas buvo atliekamas gavus Klaipédos universiteto Sveikatos mokslų fakulteto Slaugos katedros Etikos komisijos ir ịstaigos, kurioje buvo atliekamas tyrimas, vadovo leidimus. Apklausa buvo vykdoma 2019 m. balandžio 10-30 dienomis vieno iš didžiujų Lietuvos miestų GMP stotyje. Tyrimo kontingentas pasirinktas atsižvelgiant ị ịstaigos prieinamumą tretiesiems asmenims. Tiriamujų atrankos grupès: gydytojai, slaugytojos, turinčios skubiosios pagalbos specialisto kvalifikaciją, paramedikai, vairuotojai, savanoriškai tyrime sutikę dalyvauti specialistai, tyrimo laikotarpiu dirbę specialistai.

Respondentų anonimiškumas buvo užtikrinamas pateikiant anoniminius klausimynus, kuriuose nereikejjo nurodyti vardų, pavardžių, ar bet kokios kitos informacijos, leidžiančios identifikuoti respondentą. Respondentams pristatytas tyrimo tikslas, uždaviniai, atrankos dalyvauti tyrime kriterijai. Klausimai buvo pateikiami pagarbiu stiliumi, respondentai informuoti apie tyrimo naudą. Apklausos dalyviams buvo sudaryta aplinka, kurioje atsakydami i klausimus jie nejaustu baimès, paaiškinta, kaip pildyti klausimyną.

Išdalinta 80 klausimynų, kuriuose GMP specialistai turejjo pažymèti atsakymus apie komandinio darbo organizavimą ir efektyvumą, bei atsakyti ị pateiktus demografinius klausimus. Sutartas terminas, per kuri prašyta atsakyti ị pateiktus klausimus. Sugadintais klausimynais buvo laikomi tokie, kuriuose atsakyta ị mažiau nei pusę klausimų, atsakymai pažymèti netiksliai, neįskaitomai. Grįžo 60 tinkamai užpildytų klausimynų (grižtamumas - 75,0 proc.), kurie buvo panaudoti tyrimui. Duomenys apdoroti ir išanalizuoti naudojantis
Microsoft Office Word ir Microsoft Office Excel programomis. Gauti rezultatai apie komandinio darbo organizavimą ir efektyvumą susisteminti ir pateikiami procentine išraiška.

Atlikus kiekybini tyrimą ir išanalizavus gautus rezultatus, suformuluotos tyrimo išvados bei rekomendacijos GMP stoties specialistams ir ịstaigos vadovui.

\section{Tyrimo duomenu analizè}

Atliktas kiekybinis tyrimas anketinès apklausos metodu, duomenų statistinè analizè, teorinis apibendrinimas. Respondentais pasirinkti GMP istaigos specialistai. Anketa sudaryta vienos iš autorių. Mūsų tyrimo duomenys buvo palyginti su A. Ambložiejutès (2012) mokslinio darbo, skirto GMP slaugytojų darbo kokybès gerinimo galimybių tyrimui [1] bei R. Žigutienès (2014) mokslinès studijos, analizavusios Kauno regione GMP paslaugas teikiančiu darbuotojų požiūį̣ i darbo vietos saugos kultūrą, duomenimis [8]. „Greitosios medicinos pagalbos stoties specialistų komandinio darbo efektyvumas" buvo atliekamas Klaipeddos ir Vilniaus universitetuose, Respublikinèje Klaipèdos ligoninèje ir Respublikinejje Vilniaus universitetinejje ligoninejje.

\section{Rezultatai}

Sociodemografiniai GMP paslaugas teikiančių darbuotojų duomenys. I anketos klausimus atsake 60 respondentų. Pagal pareigas apklausos dalyviai pasiskirste taip: slaugytojai 55,0 proc., vairuotojai 30,0 proc., gydytojai 8,3 proc., paramedikai 6,7 proc. Tyrimo dalyviai buvo suskirstyti ị penkias amžiaus grupes: $51-60$ metų (30,0 proc.), 41-50 metų (27,0 proc.), 31-40 metu (12,0 proc.), 20-30 metu (13,0 proc.) ir $>60$ metų (18,0 proc.). Didžioji dauguma respondentų (35,0 proc.) dirba GMP daugiau nei 30 metų, 23,33 proc. - nuo 21 iki 30 metų. Dirbančių GMP nuo 11 iki 20 metų respondentų skaičius sudare 13,3 proc., nuo 6 iki10 metu $-10,0$ proc., iki 5 metu $-18,33$ procento.

Tiriamoje GMP stotyje daugiau kaip pusé specialistų $(55,0$ proc.) turi bendrosios praktikos slaugytojo licenciją. Iš jų 18,0 proc. - medicinos felčerio specialybę ịgiję darbuotojai, kurie sveikatos apsaugos ministro įsakymu (1999) buvo pervadinti bendruomenès slaugytojais, o vẻliau, ịsigaliojus Lietuvos Respublikos slaugos praktikos ir akušerijos praktikos įstatymui (2002), dar kartą pervadinti ị skubiosios medicinos pagalbos slaugos specialistus [4]. Atsiradus galimybei gilinti profesines žinias, dalis slaugytojų ( 24,0 proc.) igijo aukštaji universitetinị bakalauro išsilavinimą. Dalis vairuotoju ( $(15,0$ proc.) baigę profesinio mokymo įstaigas, 5,0 proc. - turi vidurini išsilavinimą, 6,66 proc. - aukštesnijị, o 3,33 proc. vairuotojų turi aukštaji universitetinį magistro laipsnio išsilavinimą. Rezultatai parodè, kad GMP įstaigoje dirba ịvairaus išsimokslinimo lygmens darbuotojai. Anali- 
zuoti demografiniai ir socialiniai duomenys atskleide, kad 23,33 proc. GMP specialistų yra slaugytojai, turintys aukštaji universitetinį bakalauro išsilavinimą. 35,0 proc. slaugytojų GMP dirba daugiau nei 30 metų.

Tyrimo metu apklausti 7 dispečeriai, 18 pradinio gaivinimo komandos darbuotojų (iš jų 13 slaugytojų) ir 35 pažangaus gaivinimo komandos darbuotojai (iš jų 13 slaugytojų).

Komandinio darbo aspektų analizè. Vertindami komandinio darbo situacijas, 86,67 proc. apklaustujų teigé, kad komandos nariai yra tinkamos kvalifikacijos. 10,0 proc. respondentų nurodè, kad komandos nariai kartais parenkami tinkamai, atsižvelgiama i jų kvalifikaciją, o 3,33 proc. atsakè, kad komandos nariai yra tinkami ir turi reikiamą kvalifikaciją tik iš dalies.

Komandos veiklos sèkmè labai priklauso nuo to, ar kiekvienas jos narys supranta bendrą tikslą. Kad komandos uždaviniai apibrěžti tiksliai ir aiškiai, atsakè 85,0 proc. respondentų, 1,67 proc. nurode, kad komandos uždaviniai tikslūs ir aiškūs tik kartais, o 13,33 proc. respondentų teigè, kad uždaviniai būna tikslūs ir aiškūs tik iš dalies. Net 96,67 proc. visų apklaustujjų teigè, kad siekiant gero darbo rezultato, komandoje turi dirbti visi jos nariai.

Atsakydami ị klausimus apie turimas darbo priemones ir išteklius, didžioji dauguma ( 70,0 proc.) tyrimo dalyvių teigè, kad esami ištekliai atitinka komandai keliamus uždavinius. 26,67 proc. apklaustujų nurode, kad turimos priemonès ir ištekliai kartais atitinka komandai keliamus uždavinius ir po 1,67 proc. respondentų teigè, kad turimos priemonès ir ištekliai neatitinka komandai keliamų uždavinių arba atitinka juos tik iš dalies.

Komanda turi turèti lyderị. Komandos vadovą ir jo požiūrị i darbuotojo pastangas bei sugebejjimus teigiamai ịvertino didžioji dauguma ( 93,33 proc.) visų darbuotojų. 3,33 proc. respondentų atsake, kad vadovas tik kartais vertina darbuotojų pastangas. Tiek pat (3,33 proc.) darbuotojų buvo nepatenkinti, ar tik iš dalies patenkinti, vadovo požiūriu i jų pastangas.

Kad komanda galètų sèkmingai dirbti, jos narių darbo krūvis turètų būti optimaliai paskirstytas, o užduotys konkrečios ir aiškios. Kad komandos užduotys gerai išaiškintos visoje organizacijoje ir komandos viduje, atsakè dauguma (96,67 proc.) apklaustųjų. Tik 3,33 proc. visų respondentų atsakè, kad kartais užduotys galètų būti aiškesnès. Rezultatai atskleidè, kad dauguma komandų parinktos tinkamai, profesionaliai, darbuotojai kvalifikuoti, darbas gerai organizuotas, aiškiai apibrèžtas.

Vertindami komandinį darbą, dauguma $(95,0$ proc.) respondentų atsakè, kad darbuotojai komandoje dirba darniai ir tik 5,0 proc. apklaustujų noretų daugiau bendrumo ir sutelktumo. Tai reiškia, kad apklaustieji GMP darbuotojai turi pa- kankamai žinių apie komandinį darbą, nors apklausoje apie žinių vertinimą savo komandinio darbo žinias vertino įvairiai. 73,33 proc. atsakiusiujų savo žinias vertino labai gerai, 15,0 proc. tik kartais savo žinias vertino gerai ir norejo jas gilinti. Mažiausiai žinių turèjo darbuotojai, dirbusieji mažiau nei penkerius metus. Iš jų 5,0 proc. vairuotojų atsake, kad apie komandinị darbą žinių neturi, 3,5 proc. paramedikų ir 3,5 proc. vairuotojų apie komandinį darbą žinojo minimaliai.

Dirbant komandoje labai svarbus šio darbo vertinimas. Jei darbas tinkamai vertinamas, darbuotojams atsiranda motyvacija, pasitenkinimas darbu, pasitikejjimas savimi ir šalia dirbančiu kolega. Didžiausia dalis (80,0 proc.) apklaustujų nurodè, kad jų darbas vertinamas pagal veiklos rodiklius (gaivintų ir atgaivintų pacientų skaičių). Ne mažiau svarbi ir pacientų nuomonė apie komandos darbą. Komandų klaidos vertinamos atsižvelgiant ị pacientų skundus ir siekiama komandos darbo kokybès gerinimo. Kad komandos darbas tik iš dalies vertinamas atsižvelgiant ị pacientų skundus, mano 75,0 proc. visų apklaustujų. 50,0 proc. respondentų teigia, kad pacientų pasitenkinimas komandos darbu labai svarbus, todèl būtina tinkamai atsižvelgti ị pacieto nuomonę apie GMP komandinị darbą ir nuolat su komandos nariais šia tema diskutuoti. Apie tokių diskusijų dažnį GMP komandoje apklaustujų nuomonès išsiskyrè. 82,0 proc. respondentų atsakė, kad jiems svarbi pacientų nuomonè, 3,33 proc. - svarbi tik iš dalies, 12,33 proc. - svarbi kartais ir 3,0 proc. apklausos dalyvių pacientų nuomonè yra nesvarbi.

Profesionalus medikas vertina paciento nuomonę apie atliktą komandos darbą, nes tai yra vienas iš rodiklių, matuojančių komandos darbo kokybę ir efektyvumą. Matant paciento nepasitenkinimą ir išsiaiškinant jo priežastis, galima pagerinti paslaugos kokybę. Taip igyjama patirtis, kuria galima dalintis su ką tik pradejusiais dirbti darbuotojais. Kad komandinis darbas GMP kolektyve vyktų profesionaliai ir darniai, reikalingas nuolatinis žinių tobulinimas, komandinio darbo aspektų supratimas. Kiekvienas dirbantis komandoje turi jausti asmeninę atsakomybę už atliekamą darbą. Daugiausia $(96,66$ proc.) respondentų teige, kad viena didžiausių skatinamų GMP komandinio darbo vertybių yra darbuotojų profesionalumas ir tobulejimas. 86,66 proc. apklaustujų labai palankiai vertina komandinio darbo skatinimą, 68,33 proc. apklaustujų kaip skatinamą GMP vertybę nurodè ir asmeninę darbuotojo atsakomybę.

Komandinio darbo efektyvumo analizė. Šiame skyriuje pateikiama darbuotojų nuomonè apie GMP paslaugų kokybę bei jos tobulinimo galimybes. Apklausos metu nustatyta, kad daugelis GMP darbuotojų turi didelį darbo stažą, nuolat tobulina savo žinias, veikia profesionaliai, pasiekia gerų darbo rezultatų ir yra jais patenkinti. Dauguma respondentų savo darbo GMP kokybę vertino labai gerai: 10 balų $-95,0$ 
proc., 9 balai $-3,33$ proc., 8 balai - 1,67 procento. Paprašyti apibūdinti, kaip supranta GMP darbo kokybę, 61,67 proc. respondentų nurodè būtent komandos darbą. Šie apklausos dalyviai kokybišką darbą apibūdino kaip darnios komandos veiklą ir efektyvią pagalbą pacientui. 1,67 proc. respondentų atsakè, kad komandinis darbas geras tada, kai greitai ir kokybiškai analizuojama situacija, nustatoma ir kokybiškai išsprendžiama problema. Buvo pavienių kokybiško darbo apibūdinimų: tai darbas, kurio metu sunki paciento būklè pakeičiama ị vidutinio sunkumo arba ị lengvą; kai nèra pacientų nusiskundimų; kai jauti profesini pasitenkinimą; kai pasitiki ne tik šalia dirbančia komanda, bet esamais techniniais ištekliais ir GMP valdymo sistema; kai po suteiktos pagalbos ir tolesnio gydymo pacientas grịžta ị bendruomenę visaverčiu jos nariu. Vienas atsakè, kad kokybišką darbą atskleidžia teigiami atsiliepimai ir komentarai socialiniuose tinkluose. 16,67 proc. apklaustujų neturëjo nuomonès šiuo klausimu ir i ji neatsakè.

Visi tyrime dalyvavę respondentai sutiko, kad individualūs komandos narių ịsipareigojimai yra svarbiausias efektyvaus darbo veiksnys. 71,7 proc. respondentų mano, kad mažiausiai reikšmingas efektyvaus darbo aspektas yra lyderio funkcijos pasiskirstymas. Būtent dèl šios priežasties tiriamosios GMP stoties vadovai nusprendè lyderio pozicijas skirti rotacijos būdu. Pagal vidaus tvarką ir turimas pareigybes, lyderio funkcija skiriama tik medicininị išsilavinimą turinčiam darbuotojui. Dèl to ị lyderio poziciją rotacijos būdu skiriamas gydytojas ar skubiosios pagalbos specialistas. Kiekvienas darbuotojas, paskirtas būti lyderiu, budejjimo metu gali ịvertinti komandos narių darbą. Taip atskleidžiamos techninès, psichologinès, organizacinès problemos ir klaidos. Darbuotojai skatinami teikti siūlymus gerinti paslaugos kokybę. Apklausus GMP darbuotojus, ar jiems teko teikti siūlymus dèl paslaugos kokybès gerinimo, teigiamai atsakè 80,0 proc. visu gydytojų, 36,36 proc. visu slaugytojų ir 11,11 proc. visų vairuotojų. Dauguma $(83,33$ proc.) vairuotojų nedalyvauja pasiūlymų svarstyme ir savo nuomonès apie paslaugos kokybès gerinimo priemones neišsako. Nuomonès apie paslaugos kokybès gerinimą neišreiškè paramedikai (100 proc.). Tiriamosios GMP stoties paramedikai turi mažai darbo patirties dèl nedidelio darbo stažo, o dauguma vairuotojų neturi atitinkamo išsilavinimo, todèl galima daryti išvadą, kad tai yra vieni iš veiksnių, lemiantys šios kategorijos darbuotojų pasyvumą teikti paslaugu kokybės gerinimo siūlymus.

Visi apklaustieji pareiškè savo nuomonę apie priemones didinti komandinio darbo efektyvumą. Respondentu nuomonès buvo labai skirtingos, bet dauguma (66,67 proc.) mano, kad pagrindinis efektyvumo gerinimo veiksnys yra praktiniai užsièmimai. 56,67 proc. nurodè seminarų svarbą komandinio darbo efektyvumo gerinimui, 50,0 proc. visų apklaustujų teigè, kad komandos darbą pagerintų techniniai GMP ištekliai, 51,67 proc. respondentų kartais norètų konsultantų pagalbos, o 55,0 proc. respondentų atsakè, kad komandinio darbo efektyvumas iš dalies priklauso nuo finansinio komandos paskatinimo už sèkmingai atliktą darbą.

Apibendrinant galima teigti, kad GMP dirba profesionalūs, išsilavinę, mègstantys savo darbą darbuotojai. Dauguma $(80,0$ proc.) respondentų atsake, kad yra patenkinti savo darbu. 18,0 proc. darbuotojų kartais ne visiškai patenkinti savo darbu ir tik 2,0 proc. apklaustujų iš dalies jaute pasitenkinimą atliekamu darbu.

Visi apklausos dalyviai buvo draugiški ir noriai atsakinėjo ị klausimus. İ prašymą pateikti siūlymus, kaip pagerinti GMP kokybę, pateikè įvairių pagristų ir naudingų patarimų. 10,0 proc. respondentų nurodè, kad darbo kokybei gerinti reikia kelti kvalifikaciją įvairiuose mokymuose, nuolat tobulinti praktinius igūdžius. Buvo vienas siūlymas neišskirti brigadų, dirbtinai siekiant pakelti darbuotojų kvalifikaciją ir skirti vienodą techninị aprūpinimą visoms dirbančioms brigadoms.

Vienas iš opiausių klausimų buvo darbo užmokesčio didinimas. 18,33 proc. respondentų nurode, kad didesnis atlyginimas padarytų darbą patrauklesniu jaunimui, didintų motyvaciją tobulintis ir gilinti teorines žinias. Respondentai siūlè nuolat didinti darbo užmokestị pagal turimus finansinius išteklius ir galimybes. 3,33 proc. respondentų atsaké, kad atlyginimą reikia didinti pagal kompetenciją ir matomus darbo rezulatus. Vienas iš apklaustujjų noretų ateityje matyti jaunesnio amžiaus GMP personalą. Tam tikslui siūlè GMP darbuotojus prilyginti statutiniams pareigūnams, kurie turi teisę anksčiau išeiti į užtarnautą poilsị. Respondentai pateikė siūlymų dažniau vykti ị naujausias aktualias užsienio konferencijas, šviesti visuomenę, kaip ir kada kviesti GMP, kad nebūtų nereikalingų, neproduktyvių iškvietimų, gerinti darbo operatyvumą, kuris priklauso nuo dispečerio profesionalumo, gerų ryšio priemonių bei nuo komunikacijos tarp GMP dispečerinès ir stacionarinių skubiosios pagalbos skyrių. Vairuotojai siūlè privalomaji profilaktinị techninį automobilių patikrinimą atlikti kartą per mėnesí, administracijai dažniau keisti autoparką, o įrengiant naujus automobilius, atsižvelgti i dirbančio personalo pastabas. 11,67 proc. apklaustujų neturèjo nuomonès ir pasiūlymų nerašè.

\section{Rezultatų aptarimas}

Atliktas kiekybinis tyrimas padejjo objektyviau apžvelgti komandinio darbo aspektus ir paslaugų kokybès gerinimo galimybes, išanalizuoti asmenų, dirbančiu ịstaigoje, sampratą apie komandini darbą ir jo efektyvumą, labiau įsigilinti ị analizuojamas problemas. Vidutinis GMP respondentų am- 
žius - nuo 41 iki 60 metų. 30,0 proc. apklaustujų yra nuo 51 iki 60 metų. Lyginant šiuos rezultatus su A. Ambložiejutès (2012), tyrusios GMP paslaugų kokybės gerinimo galimybes, pastebèti GMP darbuotojų amžiaus pokyčiai. Nurodytos autorès darbe 39,2 proc. GMP darbuotojų amžius buvo nuo 41 iki 50 metų. Panašaus pobūdžio studiją atliko R. Žigutienė (2014), tyrusi Kauno regiono GMP tarnybų darbo vietos saugos kultūrą. Tyrimo rezultatai atskleidè, kad tiriamoje GMP stotyje amžiaus vidurkis ( 47,0 proc. darbuotojų) buvo $>49$ metai. Tai galejo lemti demografinè šalies situacija ir didejjantis emigracijos lygis. Mūsų tyrimo rezultatai parodè, kad svarbi priežastis, dèl kurios jauni specialistai vangiai renkasi GMP darbą, yra per mažas atlyginimas, neatitinkantis jaunų žmonių poreikių. Silpniausioji GMP žmogiškujjų išteklių grandis šiuo metu yra vairuotojai, nes didžioji jų dalis neturi tinkamo išsilavinimo.

GMP stoties darbuotojų pasitenkimas atliekamu darbu aukštas. Net 80,0 proc. apklaustuju yra visiškai patenkinti savo darbu, atliekamo darbo kokybe patenkinti 95,0 proc. respondentų (10 balų). R. Žigutienès (2014) tyrime visiškas pasitenkinimas darbu siekia 86,88 proc., A. Ambložiejutès (2012) analogiškas rodiklis yra 41,9 proc., tad galima daryti išvadą, kad situacija per devynerius metus ženkliai pagerèjo. Mūsų tyrimas parodè, kad respondentai, turintys mažesni darbo stažą nei penkeri metai, dažniau teigiamai vertino pasitenkinimą darbu. Trumpesnį darbo stažą turinčių darbuotojų požiūrị galèjo nulemti naujų darbuotojų noras dirbti pasirinktą darbą ir sèkmingai prisitaikyti kolektyve. Apklausos rezultatai atskleide, kad tyrime dalyvavusiame GMP kolektyve daugiausiai skatinamas profesionalus ir nuolatinis tobulejjimas (97,0 proc. apklaustujų nuomone), 30,0 proc. visų dalyvių nuolat dalijasi savo patirtimi teikdami ìvarius pasiūlymus darbo kokybei gerinti ir didinti kolegu profesionalumą. Didžiausia darbuotojų grupė GMP tarnyboje - igijusieji nemažai darbo patirties, galintys identifikuoti darbo problemas ir komandinio darbo poreikius, siekiantys didinti darbo efektyvumą ir gerinti paslaugų kokybę.

Mūsų tyrime visi (100 proc.) respondentai teigè, kad didžiausią ịtaką efektyviam komandiniam darbui daro individualus issipareigojimas; 98,0 proc. apklaustujų įvardino komandinę atsakomybę. R. Žigutienès (2014) tyrime individualų ìsipareigojimą nurodė 96,3 proc. apklausos dalyvių. Galima daryti išvadą, kad pagrindiniai efektyvaus darbo veiksniai nesikeičia ir būtent jie, apklaustujų nuomone, lemia efektyvų komandinį darbą. Pagrindiniai veiksniai, lemiantys efektyvų komandinį GMP darbą, yra bendradarbiavimas, tarpusavio pagarba, pasitikejjimas, narių sutelktumas, komandinè atsakomybè, lyderio funkcijos pasiskirstymas, gebejjimas vertinti savo darbą ir aukšta komandos narių motyvacija. Visi (100 proc.) apklaustieji nurode, kad efektyvumą galètų pagerinti ne tik teorinès, bet ir praktinès žinios, 66,66 proc. respondentų pageidavo daugiau praktinių užsièmimų, o 50,0 proc. respondentų nurodè, kad efektyviai dirbti sunku dèl nekokybiškos technikos.

Respondentų siūlymų gerinti GMP paslaugų kokybę analizè parodè, kad darbuotojams labai svarbu ne tik profesinis tobulëjimas, bet ir darbo sąlygos. Opiausia problema - darbo užmokestis, kuris netenkina 18,33 proc. visų tyrimo dalyvių, kurie siūlè nuolat didinti GMP darbuotojų darbo užmokestį. Pagrindinė GMP brigados darbo priemonè - GMP automobilis, tad respondentai siūlè atnaujinti automobilių parką, teigdami, kad patikimas automobilis - būtina darbo priemonè, kuri turètų būti testuojama kartą per mènesį. Teikiant GMP paslaugas, labai svarbus bendradarbiavimas su kitų gydymo ịstaigų skubiosios pagalbos skyriais ir gelbejjimo tarnybomis tam, kad būtų užtikrintas saugumas ekstremaliose situacijose, siūlyta atsižvelgti ị turimas ryšio priemones ir pagal galimybę jas atnaujinti.

Šio tyrimo rezultatai atskleide, kad GMP paslaugos teikiamos profesionaliai ir koordinuotai, tačiau galimas nepageidaujamas vadovų požiūris ị veiklos vertinimą pagal pacientų skundus, darbuotojai neskatinami atvirai kalbėtis, diskutuoti bei teikti siūlymus darbo kokybei gerinti, aptarti klaidas ir mažinti stresą darbo aplinkoje. Darbuotojai nesijaučia visiškai patenkinti darbo sąlygomis atlygio atžvilgiu, brigadų rotacija, turimų techninių išteklių skirstymu. $\mathrm{Ne}$ visose sveikatos priežiūros įstaigose sèkmingai taikomas komandinio darbo modelis, todèl šio tyrimo rezultatai bus naudingi gerinti GMP stočių paslaugų kokybę, užtikrinti geresnes darbuotojų darbo sąlygas, skatinti kalbètis apie problemas, dalintis patirtimi ir pasiūlymais.

\section{Išvados}

1. Komandinis darbas yra vienas iš veiksnių, lemiančių GMP stoties specialistų veiklos sėkmę, o organizacijos darbo ypatumus atskleidžia tarpusavyje bendraujantys, tų pačių tikslų siekiantys profesionalūs komandos nariai ir vadovai, kurie parenka lyderius, atsižvelgdami ị darbuotojo kvalifikaciją, o suformuotas komandas skatina dirbti kaip darnią sistemą. Komandinis darbas yra tinkamai organizuotas, suderintas, testuojamas ir kontroliuojamas.

2. Respondentų nuomone, komandinio darbo efektyvumas priklauso nuo kiekvieno darbuotojo individualaus ìsipareigojimo. Svarbus yra narių bendradarbiavimas, tarpusavio pagarba, pasitikejimas, sutelktumas, visos komandos atsakomybė už atliekamą darbą, tinkamas lyderio pasirinkimas, gebëjimas įvertinti darbo sèkmę ir mokymasis iš klaidų. Apklausos rezultatai atskleide, kad efektyviam komandiniam darbui reikalingos teorinès ir praktinès žinios, finansinis 
skatinimas, didelė motyvacija. Koordinuotas ir tinkamai paskirstytas darbas lemia jo kokybę ir efektyvumą.

\section{Literatūra}

1. Ambložiejutė A. Greitosios medicinos pagalbos paslaugų kokybès gerinimo galimybès. Kaunas. Magistro diplominis darbas, 2012.

2. Bukartienė L., Jakimavičiūtė G., Lukianskytė R. Skubiosios medicinos pagalbos slaugos specialistu profesinio perdegimo sindromo raiška. Mokslo taikomieji tyrimai Lietuvos kolegijose, 2017;13: 39-44. http://ojs.kaunokolegija.lt/index.php/ $\mathrm{mttlk} /$ index.

3. Istomina N., Šakienė L., Bagdonas R., Bakaitė I. Komandinio darbo operacinejje efektyvumo vertinimas operacinès komandos narių požiūriu. Sveikatos mokslai, 2013;23(1):155-160.

https://doi.org/10.5200/sm-hs.2013.028

4. Lietuvos Respublikos sveikatos apsaugos ministro $1999 \mathrm{~m}$. gegužès 25 d. ịsakymas Nr. 254 "Dèl viduriniojo medicinos personalo ir jam prilygintų specialistų, dirbančių diagnostikos, gydymo ar profilaktikos darbą, bei jaunesniojo medicinos personalo pervardijimo" (negaliojantis). https://e-seimas.lrs.lt/ portal/legalAct/lt/TAD/TAIS.81063?jfwid=112c9tlurh

5. Marmienè L., Kalėdienė R., Kaselienè S., Vladičkienė J. Gydytojų ir slaugytojų požiūris ị komandinị darbą Lietuvos bendrojo pobūdžio ligoninèse. Visuomenès sveikata, 2015;2(69):48-55.

6. Šakienė L., Šalkauskienė D., Būta M., Istomina N. Slaugytojų nuomonè: komandos sutelktumo įvertinimas. Sveikatos mokslai, 2015;25(4):95-101. https://doi.org/10.5200/sm-hs.2015.079

7. Žemaitienè N., Bulotaite L., Jusienė R., Veryga R. Sveikatos psichologija. Vilnius: Tyto alba, 2011:278-281.

8. Žigutienè R. Kauno regiono greitosios medicinos pagalbos tarnybų darbo vietos saugos kultūros vertinimas. Magistro diplominis darbas. Kaunas, 2014.
9. Žuravliova T., Žiliukas G., Truš M., Mockienė V. Slaugos programos studentų rašto darbų metodiniai nurodymai. Mokomoji knyga. Klaipeda: KU leidykla, 2015.

\section{EFFECTIVENESS OF TEAMWORK WITHIN SPECIALISTS IN AMBULANCE}

\section{G. Eismontienè, L. Gedrimè, R. Žilinskienè, A. Kurienė,} E. Davydenko, N. Fatkulina

Keywords: teamwork, GMP nurse, team, emergency team, effectiveness of a team, ambulance.

Summary

Teamwork is especially important in emergency services as the quality of collaboration determines the state of health and survival of the patient. The structure of an ambulace (later GMP) is the same in entire Lithuania - it consists of dispatcher centre, acting as a coordinator, and brigades. The latter ones contain no less than two people, whereas one of them is a leader making decisions and keeping in touch with dispatcher centre.

The purpose of this paper is to evaluate the effectivness of GMP teamwork from the team members perspective.

In one of the major cities of Lithuania a quantitative study has taken place in April 2019, involving 60 different ambulance specialists, including doctors, nurses, dispatcher nurses, paramedics and drivers.

Results and conclusions. In the immense variety of different teams it is important to understand where one belongs as well as what are the tasks, goals and perspectives of the specific team. The importance of teamwork in personal healthcare sector is related with the needs of employee collaboration in different specializations. Teamwork allows to save and improve usage of finances and human health care resources, ensure a better service quality and reduce the likelihood of treatment errors. The study could be of benefit to both service providers (GMP teams) and service users (patients).

Correspondence to: linagedrimaite@gmail.com

Gauta 2020-02-04 